\title{
Role of Trichoderma and Sinorhizobium Strains for Improving Growth and Nutritional Status of Alfalfa under Cd Stress
}

\author{
Dr. Najia Shwerif \\ Department of Plant Science, Gharian University, Libya \\ Email: alshwerif@yahoo.com
}

\begin{abstract}
The plant rhizosphere is a major soil ecological environment for plant- microbe interactions involving colonization of different microorganisms in and around the roots of the growing plant. Plants can be used in the remediation of soils contaminated with heavy metals. The objective of this study was determine the relationship between the effect of $\mathrm{Cd}$ on the symbiotic model of Sinorhizobium meliloti - Medicago sativa and the application of Trichoderma sp. on the nutritional status as well as biochemical characterization of the sandy brown forest soil. The effects of biofertilizer Sinorhizobium and coinoculants Trichoderma strains on growth, chlorophyll and $N, P$ and $K$ content of alfalfa growing in soil polluted by cadmium were investigated.

The results indicate that the presence of the saprobe fung $i$ Trichoderma harzianum further enhanced shoot dry weight, $N, P$ and $K$ content of Sinorhizobium melilotialfalfa symbiotic model. The co-inoculation of alfalfa with T. harzianum was more effective for $\mathrm{Cd}$ uptake. The effects of the bio-multiple inoculants on the growth of alfalfa were stimulated the colonization of Sinorhizobium strains in the rhizosphere, promoted the nodulation potential and increased the dry organic matter. Sinorhizobium meliloti interacts with alfalfa as a model for rhizobioremediation and Trichoderma strains interact with this model as nodule promotors as well as a partner in the process of cleaning the plant rhizosphere from cadmium metal.
\end{abstract}

Keywords-Alfalfa (Medicago sativa), heavy metals, Sinorhizobium, Trichoderma fungi.

\section{INTRODUCTION}

Soil are reservoirs for heavy metals generated by industrial activities e.g. metal finishing, paint pigment and battery manufacturing, leather tanning, mining activities, municipal waste water sludge, urban composts, pesticides, phosphate fertilizer, or from atmospheric depositions (Ariano, 1986, Kabata-Pendias, 1992). Metalliferous or industrial soil, which is heavily enriched with toxic metals, can support the growth of specific plant species called metallophytes, which have long attracted the interest of botanist and are now considered as potential tools for phytoremediation (phytostabilization or phytoextraction). Some of these hypertolerant plants also have the ability to accumulate high concentration of metals in their tissues,(Boularbah et al., 2006). Approximately 450 plant species have been classified as hyperaccumulators of heavy metals, (Baker et al., 1994; Morel et al., 1997).

The health hazards associated with soil contamination with trace elements having toxic effects together with high cost of removal and replacement of polluted soil have prompted to develop alternative and cheaper technologies to recover the degraded land. Current research in this area now includes plants to remediate polluted soils and to facilitate improvement of soil structure, the innovative technique being known as phytoremediation (Brooks, 1998). The possibilities of using such plant species which are easily growing in different climates, and using their biomass in non-food industries, can make them ideal plants for phytoremediation purposes (Linger et al., 2002; Khan, 2003). Phytoremediation must be considered as a longterm strategy (Cunningham et al., 1995).

Since 1904, when the term rhizosphere was first coined by Hiltner (1904), rhizosphere processes of plants have been widely investigated, however, little attention has been paid to the microbial community of rhizospheres of plants growing on metal contaminated sites. Soil microorganisms, including plant root associated freeliving as well as symbiotic rhizobacteria and mycorrhizal fungi in particular, are integral part of the rhizosphere biota. The overall result of plant-rhizosphere microbe interactions is a higher microbial density and their metabolic activity in the rhizosphere, even in metal contaminated soils (Vander, 1998). Plants also influence the structure of microbial communities through the release of root exudates (Grayston and Campbell, 1996, Grayston et al., 1996; Grayston et al., 1998; Kozdroj and Van Elsas., 2000) and by providing surfaces for 
colonization. However, it is not understood how specific plants increase the remediation of contaminated soil (Kirk et al., 2005).

Alfalfa is the most important forage crop in the world. The seed germination and vigor condition of alfalfa seedling are characteristics that determine plant establishment and initial crop development. Many leguminous plants and particularly alfalfa have extensive soil-root system extending as deep as $2 \mathrm{~m}$. Rhizosphere or soil-root systems limit the diffusion of solutes in the soil. Hence the plant can serve both as a vehicle for limiting the spread of solutes and by promoting the mineralization of the toxic compound. The general feasibility of rhizosphere approaches to remediation has been previously demonstrated (Anderson and Coat 1994). Frequently, alfalfa development is hampered by environmental conditions, such as metal deficiencies and metal toxicity, as well as by diseases. Previous investigations have shown that common root-colonizing bacteria are plant growth-promoting microorganisms that can improve plant development under a variety of environmental conditions (Reynders and Vlassik 1982, Kapulnik et al. 1985, Sarig et al. 1988), however, the known mechanisms by which they promote plant growth are quite variable. Some of them promote plant growth mediated by their production of plant regulators (Mordukhava et al. 1991). Previous studies demonstrated that alfalfa plants have the ability to geminate and grow in montmorillonite clay individually contaminated with 80 $\mathrm{mg} / \mathrm{kg}$ of $\mathrm{Cd}, \mathrm{Cu}$ and $\mathrm{Ni}$ and $160 \mathrm{mg} / \mathrm{kg}$ of $\mathrm{Zn}$ (PeraltaVidea et al. 2002). Based on that information, the following research was designed to determine if a correlation exists between the heavy metal tolerance and the growth stage of alfalfa plants. The rhizosphere also affects the availability of heavy metals. Early studies have indicated that there is higher concentration of exchangeable and carbonate bound $\mathrm{Cr}, \mathrm{Ni}, \mathrm{Zn}, \mathrm{Cu}, \mathrm{Pb}$ and $\mathrm{Cd}$ in the rhizosphere than in bulk soil (Wang et al., 2002). Root -induced changes in the rhizosphere are important factors controlling nutrient dynamics in this zone and thus the mineral nutrition of plants. On the other hand, nutrient dynamics also influence the rhizosphere environment (Stratton et al., 2001). Rhizobia (e.g. Azorhizobium, Rhizobium and Sinorhizobium species) are soil bacteria able to develop N2-fixing symbiosis with legume plants. S. meliloti is a Gram-negative bacterium that can live as a saprophyte in soil or as $\mathrm{N}$-fixing symbiont inside root nodule cells of alfalfa. Fewer studies are the activities of nodulating bacteria in the rhizosphere of the host plants that are important for host infection. These processes include communication between bacteria (Gray et al., 1996), competition for access to infection sites on root (Tripplett and Sadowsky, 1992), gene transfer (Sullivan and Ronson, 1998) and the growth in the rhizosphere (Robleto et al., 1998).

\section{MATERIALS AND METHODS}

2.1 Microorganisms: in addition to the new isolates of Sinorhizobium meliloti strains (isolated from different root-nodules on root of alfalfa, which grown in $50 \%$ sewage sludge amended brown forest soil), two standard strains of $S$. meliloti ( heavy metal- tolerant strain GHR94 and salt-tolerant strain GH130) and Trichoderma strains (T. harzianum (111-2b), T. viride (131-2) and T. koningii $(\mathrm{Cu}-3))$ isolated from heavy metal contaminated soil Nagyhörcsök, Gyöngyös and Eger, Hungary respectively were obtained from the Gene bank of Culture Collection of the former Research Group of Environmental Microbiology of Hungarian Academy of Sciences.

2.2 Cultural media and test plant: all medial constituents were purchased from Difco Laboratories, Sigma, or Merck Co. Experiments employed the following sterilized media were used for maintained the tested microbial strains as slant cultures as well as carrying out the investigations: Medium for Sinorhizobium :(1) Yeast extract mannitol agar: Sinorhizobium meliloti isolates were isolated and maintained on yeast extract mannitol agar (YMA) described by Kleczkowska et al., (1968). (2) Yeast extracts mannitol broth: YMA medium without agar (YMB).

Medium for Trichoderma: (1) Trichoderma- selective medium: Trichoderma strains were maintained on Trichoderma- selective medium described by Askew and Laing ., 1993). (2) Sucrose-yeast extract broth (SYB): for preparation of bioinoculant and to study the sensitivity of the Trichoderma strains to $\mathrm{Cd}$ salts. Different concentrations of $\mathrm{Cd}$ salts were added to SYB medium described by Altomare et al., (1999). Alfalfa (Medicago sativa L.) seeds of Hungarian origin.

2.3 Soil sample collection and preparation: the experiments were carried out in pots with soil contaminated by cadmium salts ( $\left.\mathrm{Cd} 11.02 \mathrm{mg} \mathrm{kg}^{-1}\right)$. The soil sample used for the present study was collected from a non-cultivated field of the experimental station at Szent István University, Hungary. The soil of sampling area was sandy brown forest of general properties. The soil sample were collected in plastic bags and transferred to the laboratory. The sample was sieved through a $2 \mathrm{~mm}$ mesh to remove plant debris and soil fauna and was stored at cool room for plant-microbe interaction.

2.4 Cadmium salt: cadmium chloride $\left(\mathrm{CdCl}_{2} .6 \mathrm{H}_{2} \mathrm{O}\right)$ and

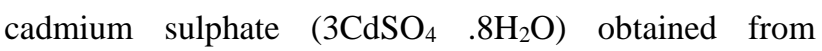
(Reanal Chemical Company Ltd), with following concentrations used: In vitro: 0, 10, 20, 40, 80 and $160 \mu \mathrm{M}$. In vivo: $0,10,20,40,80$ and $160 \mathrm{mg} \mathrm{kg}^{-1}$ soil. 
2.5 Isolation, maintenance and growth of Sinorhizobium meliloti:

Routine techniques for further studies of Rhizobium are described by Vincent, (1970) were used. Comparatively, the isolates were selected according to the intense pink coloration of the colonies. Sub-culturing occurred only once during the experiment and single colonies were selected and each isolate was restreaked to purify (Somesegaran and Hoben., 1994). The bacterial isolates were stored on YMA slant tubes for further investigation. In screw-capped tubes containing YMA with $\mathrm{CaCO}_{3}(3 \mathrm{~g} 1$ ${ }^{-1}$ ), the strains were streaked and maintained at $4^{\circ} \mathrm{C}$.

\subsection{Screening isolates for nodulation:}

A test of ability of the 55 isolates to form nodules on alfalfa root is the ultimate criterion of authenticity as Sinorhizobium. According to Jansen and Strijdom., (1982) that competitive ability as determined in autoclaved soils correlated with the ability to infect plants rapidly. The selection of the strains were depended on the intensity of nodule formation on the root (occupation rate in comparison with control strains), and the presence of leghemoglobin formation inside the root- nodule (the pink color) in which the concentration of leghemoglobin within the nodule bears a direct relationship to the amount of molecular N2-fixed (Jordan and Garrard., 1951).

2.7 Preparation of inoculate: under complete aseptically conditions, the inoculate of tested Sinorhizobium meliloti strains were prepared by growing each microorganism of tested bacterial cultures in $250 \mathrm{ml}$ Erlenmeyer flask containing $50 \mathrm{ml}$ of YMB medium. The flasks were incubated at $28^{\circ} \mathrm{C}$ for 2 days on a rotary shaker operating at $150 \mathrm{rpm}$. The bacterial cells from $10 \mathrm{ml}$ cultures were centrifuged (12000 x for $4 \mathrm{~min}$ ) and washed twice in phosphate buffered saline and re-suspended in $10 \mathrm{ml}$ of phosphate buffered. This is the final bacterial suspension which was used as inoculum throughout the following investigations.

Preparation of sinorhizobial inocula for in vitro: All Sinorhizobium inocula used in in vitro experiments had a cell capacity of $1 \times 10^{6}$ cell ml-1 of saline solution $(0.85 \mathrm{~g}$ $\mathrm{NaCl}$ salt dissolved in sterile distilled water and completed to $100 \mathrm{ml}$ ), this was calibrated by haemocytometer. It was prepared by washing three slant cultures of a $24 \mathrm{~h}$ old culture, each with $5 \mathrm{ml}$ of sterile $0.85 \% \mathrm{NaCl}$ solution. The uniform distribution of the cells in the solution was obtained by shaking machine (Bayoumi, 1987). For in vitro experiments, Trichoderma strains a colony disc of active mycelium of fresh growth colony with $5 \mathrm{~mm}$ in diameter was placed carefully in the $250 \mathrm{ml}$ Erlenmeyer flask containing $50 \mathrm{ml}$ of SYB medium. The flasks were incubated at $28^{\circ} \mathrm{C}$ for 5 days on a rotary shaker operating at $50 \mathrm{rpm}$. But, in vivo for soilplant inoculation, conidial suspension was prepared by washing the growth colony grown on agar surface with saline solution and the conidial number per $\mathrm{ml}\left(1 \times 10^{4}\right)$ was calibrated by haemocytometer.

2.8 Ecophysiological selection of $\mathrm{S}$. meliloti strains: originally, the total number of isolates was 55 , and by the help of nodulation test, the number of root nodule forming strains was reduced to 18 during one month.

\subsection{Determination the growth rate of microbial strain} under Cd stress

For Sinorhizobium strains: two cadmium salts were subjected to establish their effects on the growth rate of 8 $S$. meliloti strains in YMB medium using microfermentor technique (Bayoumi et al., 1995a and 1995b) at six concentration $\left(0,10,20,40,80\right.$ and $\left.160 \mathrm{mgl}^{-1}\right)$ of each salt. Using spectrophotometer (DR-2000 model) under different conditions at wavelength $550 \mathrm{~nm}$ and compared with the rate of growth in control culture.

For Trichoderma strains, a colony disc of active mycelium of fresh growth colony with $5 \mathrm{~mm}$ in diameter was placed carefully in the center of in $250 \mathrm{ml}$ Erlenmeyer flask containing $50 \mathrm{ml}$ of SYB medium contaminated with two cadmium salts at different concentrations $\left(0,10,20,40,80\right.$ and $\left.160 \mathrm{mgl}^{-1}\right)$. The flasks were incubated at $28^{\circ} \mathrm{C}$ for 5 days on a rotary shaker operating at $50 \mathrm{rpm}$.

\subsection{Phytoremediation of Cd polluted soil:}

The soil remediation ability of the plant-bacteria symbiosis was tested using a sterilized soil with or without $\mathrm{Cd}$ contamination, which was supplied as $\mathrm{CdCl}_{2}$ or $\mathrm{CdSO}_{4}$ solution to obtain a Cd concentration of 0,60 , and $120 \mathrm{mgkg}^{-1}$ dry weight soil. The pots contained a mixture of each $4 \mathrm{~kg}$ of soil and approximately $1 \times 10^{6}$ cells of sinorhizobial strain per seedling. Six seedlings of alfalfa, which were three days old after germination (M.sativa seeds were surface-sterilized, sown $0.7 \%$ agar plate and incubated for three days in the dark at $25^{\circ} \mathrm{C}$ ), were transferred to one pot containing one of $\mathrm{Cd}$ concentration mentioned above in addition to one of Trichoderma strains and grown under light (16h photoperiod per a day) at $25-28^{\circ} \mathrm{C}$ for 8 weeks. Shoots, roots and nodules were harvested from 8 weeks-old plants. Cd concentration was measured directly from the soluble fraction using AAS.

\subsection{Monitoring the biological $\mathrm{N}_{2}$-fixation under $\mathrm{Cd}$} stress:

The experiment was designed to detect the interactions between the two cadmium salts amendment and the biological $\mathrm{N}_{2}$ fixation in brown forest soil. The study was conducted in pot experiment predicated to different concentrations of cadmium doses. The cadmium salts were applied to the soil before the plantation and plant inoculation. Generally, the following experiments of predicating the impacts of cadmium on the plant-microbe 
interactions in addition to coinoculate the system with Trichoderma strains (H1-2b T. harzianum, 131-2 T.viride) were carried out using one Hungarian cultivar of alfalfa, three new isolated strains of S. meliloti (GHF-162, GHF-281 and GHF-3153), one standard strain (GHR-94) and two cadmium salts at three concentrations $(0,60$ and $120 \mathrm{mg} \mathrm{kg}^{-1}$ soil) and performed in the greenhouse.

Seeds were selected for healthy and uniformity without any injury, and surface sterilized with $70 \%$ ethanol followed by acidified $0.2 \% \mathrm{HgCl}_{2}$ for 5 minutes, and thoroughly washed in several changes of sterile distilled water. Seeds were then soaked for $8 \mathrm{~h}$ at room temperature in sterile distilled water (soaking water was changed every $2 \mathrm{~h}$ ) and then seeds were germinated on sterile moisted filter paper in large petri dish for $72 \mathrm{~h}$ in the dark at $28^{\circ} \mathrm{C}$ according to Franco and Vincent, (1976). Sterile water was added to the germinated seeds when required. Under a sceptic conditions, eight seedlings were transplanted into each pot and covered with a layer of approximately $2 \mathrm{~cm}$ of sterile soil. Pots were cellophane covered. Seven days after transplanting, pots were thinned to four seedlings pot $^{-1}$. Seedling rhizosphere was inoculated with $10 \mathrm{ml}$ of a suspension of biofertilizer Sinorhizobium inoculum (GHR-94, GHF-162, GHF-281, or GHF- 3153) prepared as follows: each one of the five biofertilizer $S$. meliloti strains was grown in YMB for $48 \mathrm{~h}$ at $28^{\circ} \mathrm{C}$, to give a final cell concentration $1 \times 10^{6}$ cell capacity $\mathrm{ml}^{-1}$, using hemocytometer for calibration. Seedlings were watered with sterile tap water when required, and the plants grown under natural illumination $14 \mathrm{~h}$ photoperiod at around $28 \pm 2^{\circ} \mathrm{C}$ according to Ta and Faris, (1988). Consequently, the inoculated plant seedlings were coinoculated with one of the following Trichoderma harzianum (H1-2b) or Trichoderma viride (131-2).

The experiment was conducted in three replicate for each of treatment. Seedlings were watered with sterile distilled water when required. The plants were grown under natural illumination (16h photoperiod) at around 26$18 \pm 2{ }^{\circ} \mathrm{C}$. The experiment was conducted for 8 weeks, and then plants were carefully uprooted, and washed several times in tap water for farther investigations.

\subsection{Plant growth parameters:}

Data recorded/ plant as follows: Height of plant shoot in $\mathrm{cm}$, number of root nodules. Dry weight of plants biomass and nodules were determined after oven dried at $75^{\circ} \mathrm{C}$ to a constant weight and the values were expressed as g plant $^{-1}$ and $\mathrm{mg}$ root nodules plant ${ }^{-1}$. Total N-content (mg plant ${ }^{-1}$ ) was measured using micro-Kjeldahl method as a criterion of $\mathrm{N}_{2}$-fixation (Burris, 1974). $\mathrm{Cd}$ concentrations were measured after digestion of the airdried plant samples with $\mathrm{HNO}_{3}+\mathrm{H}_{2} \mathrm{O}_{2}$, followed by inductively coupled plasma atomic emission spectrometry (ICP- AES), as described by Mikanova et al., (2001).

\subsection{Measurement of chlorophyll and total $N, P$ and $K$ contents:}

The chlorophyll $\mathrm{a}$ and $\mathrm{b}$ of alfalfa leaves was extracted with $80 \%$ (v:v) acetone at 8 weeks after transplanting and estimated by a procedure as described by Lichtenthaler, (1987). The sample size for this measurement was a $5 \mathrm{~mm}$ diameter leaf. The total N, P and K contents in shoots of alfalfa plants were analyzed as described by Mingorance, (2002) using a microwave system after digestion of samples with $\mathrm{H}_{2} \mathrm{SO}_{4}+\mathrm{H}_{2} \mathrm{O}_{2}$. Total $\mathrm{N}$ and $\mathrm{P}$ were determined by colorimetry using automatic air-segment continuous flow analysis and $\mathrm{K}$ was analyzed by flame photometry.

\subsection{Statistical analyses}

Values are mean of three to eight replicates. All data were subjected to one-way analysis of variance. Data were processed by analysis of variance (ANOVA) and Fisher's protected least significant differences (LSD) when appropriate (Sokal and Rohlf 1981).

\section{RESULT}

\subsection{SELECTION OF $S$. MELILOTI STRAINS}

Using different microbiological assays and the growth on various growth media and pure cultures, the number of the isolates was reduced. Therefore, a final 18 out of 55 bacterial isolates were collected from different rootnodules of various plant samples and then this number of isolates was reduced by the help of plant inoculation to become 8 according to the faster and early development of root nodules on the roots of alfalfa plants.

\subsubsection{Performance of nodulation formation and plant dry weight}

Table 1 shows the differences between the strains on the competitive ability in the nodule formation (nodule number per plant). When the strains have the ability to form nodule, it means that they are able to survive and multiply in the environment under normal conditions (without stressed factors). These results gave an account on the mode of the strains to colonize the rhizosphere and the roots of the host plant. 
Table 1. Plant dry weight and number of nodules per plant as criteria for the ability to form effective N2-fixing nodules with the host plant (authentication).

\begin{tabular}{|l|c|c|}
\hline Inoculation with isolates & Plant dry matter (mg) & Number of nodules per plant \\
\hline Uninoculated plant & 153 & 0 \\
\hline Standard: GHR-94 & 231 & 10 \\
\hline Standard: GH-130 & 254 & 10 \\
\hline GHF-131 & 241 & 14 \\
\hline GHF-162 & 412 & 9 \\
\hline GHF-1120 & 225 & 9 \\
\hline GHF-1141 & 228 & 10 \\
\hline GHF-214 & 244 & 13 \\
\hline GHF-230 & 312 & 10 \\
\hline GHF-243 & 267 & 11 \\
\hline GHF-270 & 281 & 14 \\
\hline GHF-281 & 457 & 11 \\
\hline GHF-290 & 288 & 13 \\
\hline GHF-2100 & 315 & 12 \\
\hline GHF-2130 & 309 & 11 \\
\hline GHF-321 & 297 & 13 \\
\hline GHF-353 & 326 & 13 \\
\hline GHF-372 & 317 & 12 \\
\hline GHF-3111 & 303 & 13 \\
\hline GHF-3150 & 331 & 14 \\
\hline GHF-3153 & 461 & \\
\hline
\end{tabular}

\subsection{In vitro tolerance of inoculant strains to $\mathrm{Cd}$ salts}

\subsubsection{For sinorhizobial biofertizer inoculants:}

The effect of cadmium in chloride and sulfate forms on the relative growth rates of the selected Sinorhizobium strains are presented in Fig $1 \& 2$. The percentage relative growth of sinorhizobial strains was obtained in comparing with the control. Results clearly demonstrate that the addition of cadmium affected growth conditions differentially with the concentrations of the salt. It was found that by increasing the $\mathrm{Cd}$ concentration in the growth medium the growth rate of the strains decreased. But, GHR-94, GHF-162, GHF-281 and GHF-3153 strains of Sinorhizobium were the most tolerant against the concentrations of $\mathrm{CdCl}_{2}$ (Fig 1). Similar results were obtained in case of treated the growth medium with $\mathrm{CdSO}_{4}$ (Fig 2). This figure shows that the relative growth rates of the strains were more inhibited by concentrations of the salt investigated. Comparatively, it was found that the effect of sulfate form of the cadmium salt was more toxic to the Sinorhizobium strains. 


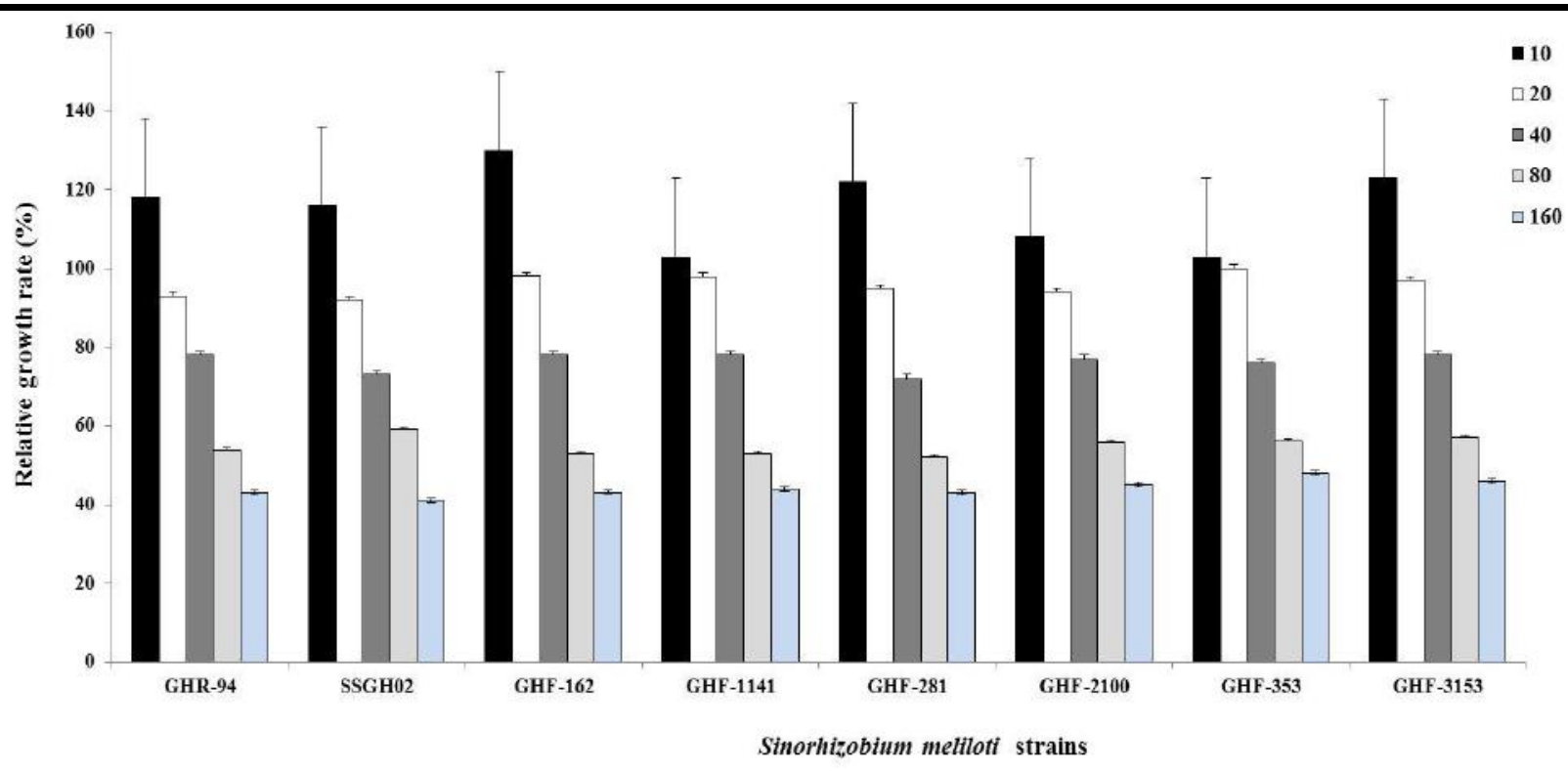

Fig. 1: Effect of cadmium chloride concentrations on the relative growth rate Sinorhizobium meliloti strains.

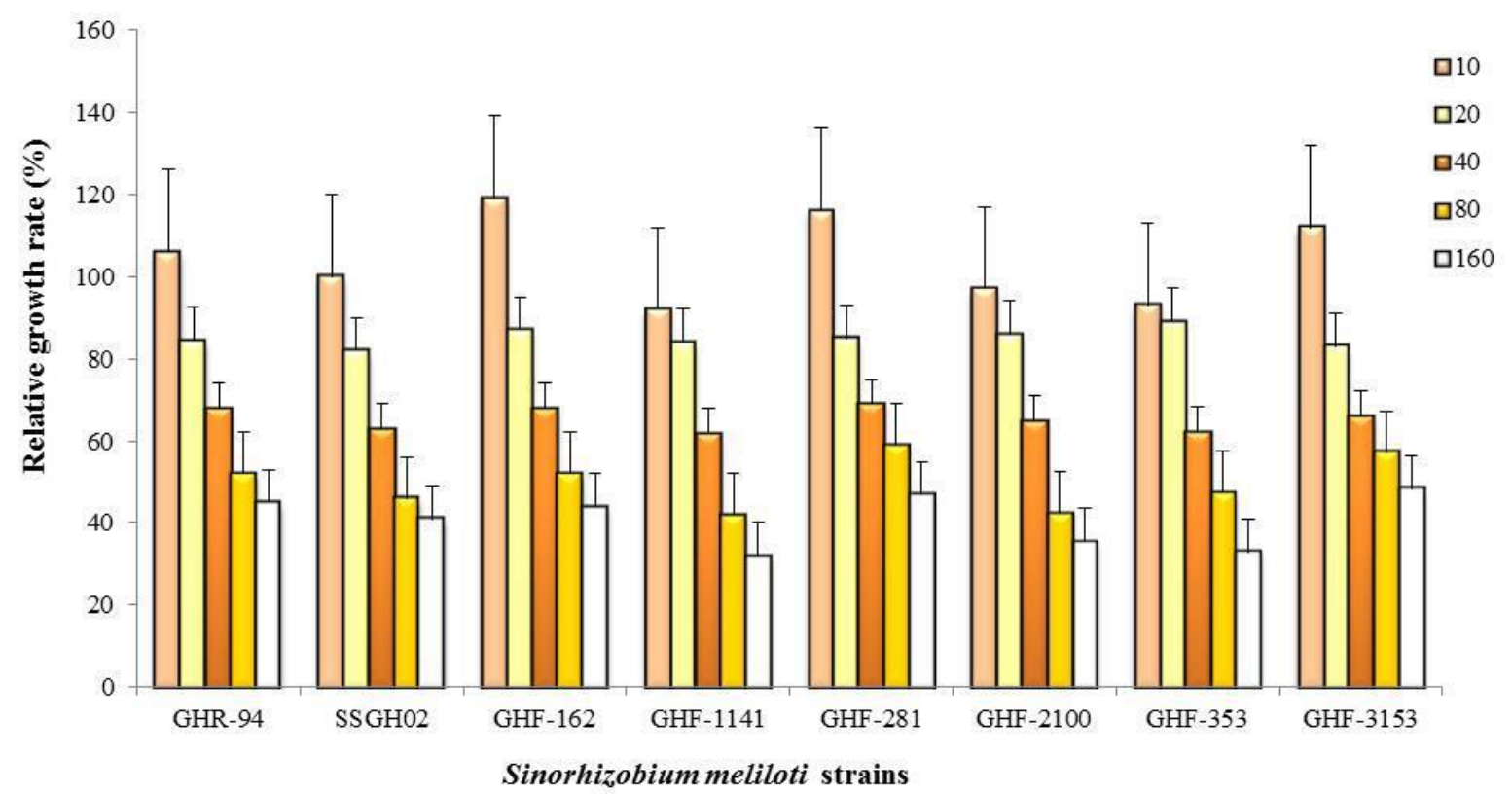

Fig. 2: Effect of cadmium sulfate concentrations on the relative growth rate Sinorhizobium meliloti strains

\subsubsection{For Trichodermal coinoculants:}

In SY broth medium, effect of different concentrations $(0$, $10,20,40,80$ and $160 \mathrm{mgl}^{-1}$ ) of Cd salts were tested and the results showed that the Trichoderma strains were tolerated the low concentrations in term of dry weight of fungal colony. But by increasing the concentrations the dry weight of fungal colony was decreased. Fig 3 shows that no significant differences among the strains toward $\mathrm{CdCl}_{2}$ concentrations, and the T. harizanum (H1-2b) was more tolerant strain andCu-3 of $T$. koningii was more sensitive to the $\mathrm{CdCl}_{2}$. Fig 4 demonstrates that $T$. harizanum was the most tolerant strain to $\mathrm{CdSO}_{4}$ than $T$. viride and T. koningii. Comparatively, the results of this investigation showed that $\mathrm{CdSO}_{4}$ had more toxic effects on the colony dry weight of the three Trichoderma strains than $\mathrm{CdCl}_{2}$. 


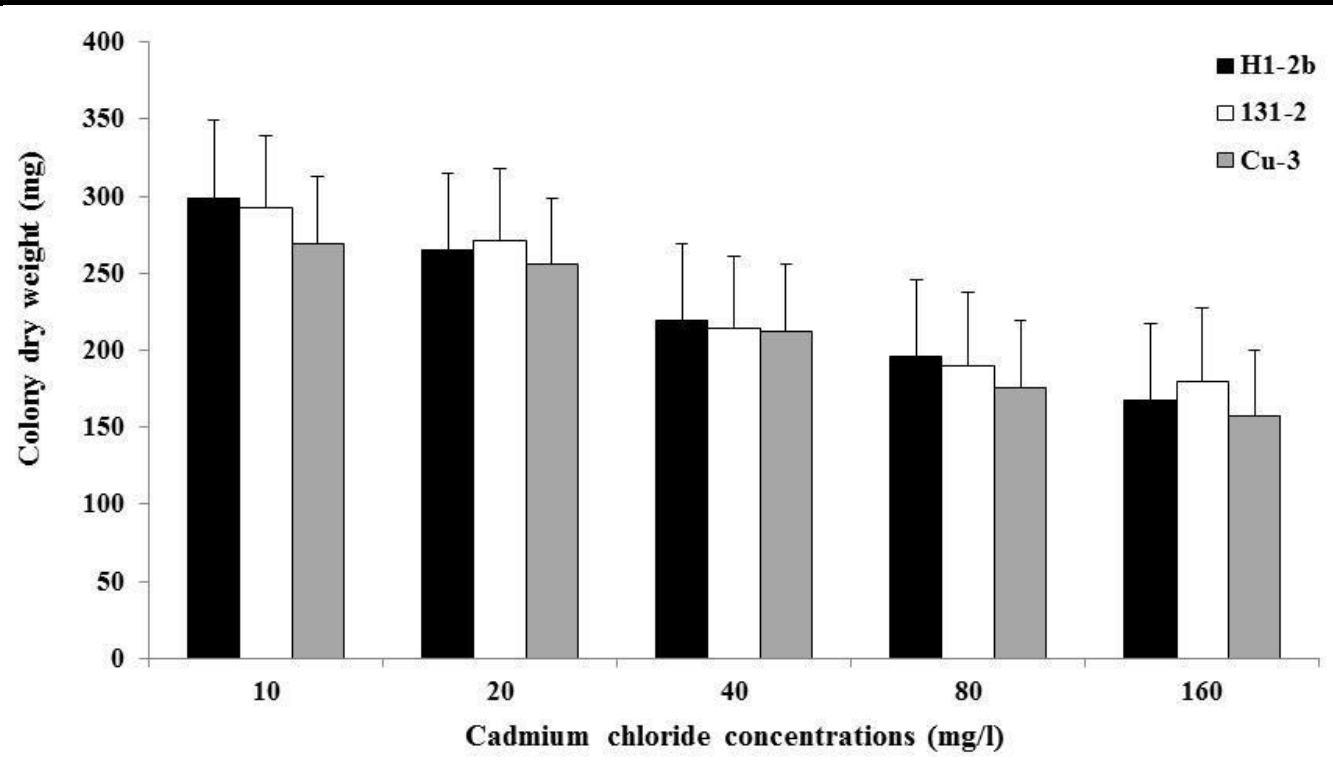

Fig. 3: Effect of cadmium chloride on the colonial dry weight of Trichoderma strains

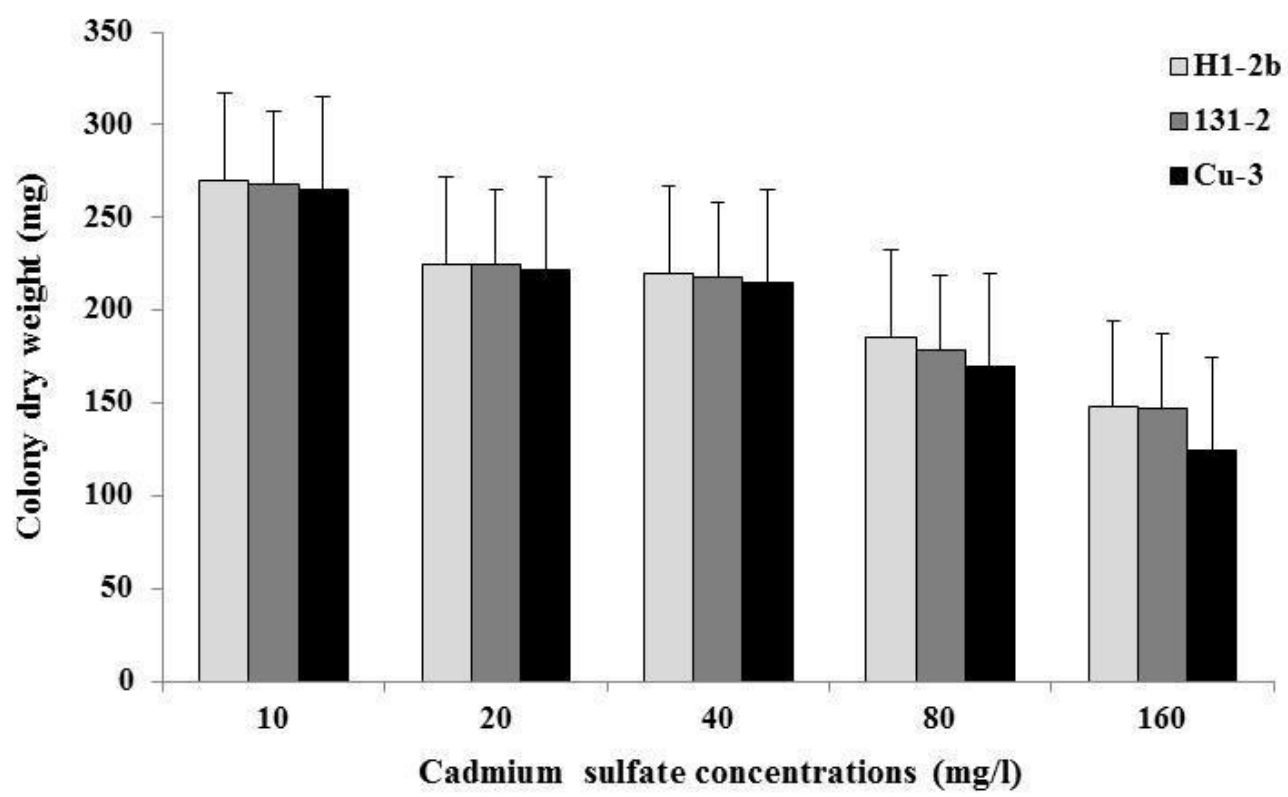

Fig. 4: Effect of cadmium sulfate on the colonial dry weight of Trichoderma strains

\subsection{In vivo experiments}

\subsubsection{Effect of Cd on plant biomass}

Generally, the addition of Trichoderma strains to the Cdtreated soil as co-inoculating agent improved the plant biomass (shoot and root) of the plant inoculated by four $S$. meliloti strains. The results for the effect of cadmium on the biomass of the alfalfa plants with the inoculants and coinoculants are present in Table 2. All plants were grown even in the presence of the highest concentration (120mg Cd/kg soil). In all cases of the $\mathrm{Cd}$, the biomass per plant varied directly with the metal concentrations applied to the soil and depended on the biofertilizer and coinoculants strain. There were significant differences between the biomass throughout the all plants and the highest concentration of $\mathrm{Cd}$ applied to the soil. Moreover, that biomass which was measured at $60 \mathrm{mg} / \mathrm{kg}$ was significantly increased compared with those at $120 \mathrm{mg} / \mathrm{kg}$. The results of this study showed that the coinoculation with T.harzianum gave more nodule numbers compared with those coinoculated with $T$. viride strains especially when the plant inoculated by GHF-3153 followed by GHF-281, GHF-162 and GHR-94. It was noted that the $\mathrm{R} / \mathrm{S}$ ratios were high in all cases which were coinoculated with Trichoderma strains and this gave evidence that the Trichoderma strains are proved to be plant growth promoting agents. Previously, in the present work, it was 
found that the two strains of Trichoderma are proved also to be nodule promoting agents due to the increasing the nodule numbers compared with those grown on the roots of plants only inoculated with the biofertilizers. The

Table.2: Shoot and root dry weight of Medicago sativa grown in Cd-contaminated soil at concentrations 60 and $120 \mathrm{mg} / \mathrm{kg}$ soil and inoculated with Sinorhizobium meliloti in presence or in absence of Trichoderma harzianum and Trichoderma viride strains results indicated that the soil amended with $\mathrm{CdSO}_{4}$ had more toxic effect on the investigated parameters of shoot and root dry weight and $\mathrm{R} / \mathrm{S}$ ratio than $\mathrm{CdCl}_{2}$.

\begin{tabular}{|c|c|c|c|c|c|c|}
\hline \multirow[t]{2}{*}{ Treatments } & \multicolumn{2}{|c|}{ Shoot dry weight (g) } & \multicolumn{2}{|c|}{ Root dry weight (g) } & \multicolumn{2}{|c|}{$R / S$ ratio } \\
\hline & T.harzianum & T. viride & T.harzianum & T. viride & T.harzianum & T. viride \\
\hline Control & 1.76 & 1.72 & 0.42 & 0.41 & 0.21 & 0.21 \\
\hline Control+60mg CdCl${ }_{2}$ & 2.02 & 1.95 & $0.55 \mathrm{a}$ & $0.54 \mathrm{a}$ & $0.3 \mathrm{a}$ & 0.28 \\
\hline Control+120mg CdCl 2 & 1.96 & 1.94 & 0.59 & $0.57 \mathrm{a}$ & $0.32 \mathrm{a}$ & $03 a$ \\
\hline GHR-94+60mg CdCl 2 & $2.24 \mathrm{a}$ & $2.16 \mathrm{a}$ & $0.67 \mathrm{a}$ & $0.61 \mathrm{a}$ & $0.4 \mathrm{a}$ & $0.38 \mathrm{a}$ \\
\hline GHR-94+120mg CdCl 2 & $2.11 \mathrm{a}$ & $2.03 a$ & $0.61 \mathrm{a}$ & $0.62 \mathrm{a}$ & $0.35 \mathrm{a}$ & $0.29 \mathrm{a}$ \\
\hline GHF-162+60mg CdCl 2 & $2.25 \mathrm{a}$ & $2.34 \mathrm{a}$ & $0.66 \mathrm{a}$ & $0.64 \mathrm{a}$ & $0.41 \mathrm{a}$ & $0.33 \mathrm{a}$ \\
\hline GHF-162+120mg CdCl & $2.08 \mathrm{a}$ & 2.02 & $0.69 \mathrm{a}$ & $0.63 a a$ & $0.4 \mathrm{a}$ & $0.38 \mathrm{a}$ \\
\hline GHF-281+60mg CdCl 2 & $2.68 \mathrm{a}$ & $2.61 \mathrm{a}$ & $0.76 \mathrm{a}$ & $0.72 \mathrm{a}$ & $0.45 \mathrm{a}$ & $0.41 \mathrm{a}$ \\
\hline GHF-281+120mg CdCl & $2.58 \mathrm{a}$ & $2.49 \mathrm{a}$ & $0.74 a$ & $0.64 \mathrm{a}$ & $0.48 \mathrm{a}$ & $0.45 \mathrm{a}$ \\
\hline GHF-3153+60mg CdCl ${ }_{2}$ & $2.77 \mathrm{a}$ & $2.68 \mathrm{a}$ & $0.81 \mathrm{a}$ & $0.70 \mathrm{a}$ & $0.49 \mathrm{a}$ & $0.48 \mathrm{a}$ \\
\hline GHF-3153+120mg CdCl 2 & $2.72 \mathrm{a}$ & $2.64 \mathrm{a}$ & $0.77 \mathrm{a}$ & $0.69 \mathrm{a}$ & $0.49 \mathrm{a}$ & $0.48 \mathrm{a}$ \\
\hline Control+60mg CdSO ${ }_{4}$ & 1.85 & 1.81 & 0.52 & 0.5 & 0.26 & 0.26 \\
\hline Control+120mg CdSO${ }_{4}$ & 1.76 & 1.74 & 0.49 & 0.47 & 0.27 & 0.26 \\
\hline GHR-94+60mg CdSO $_{4}$ & 1.95 & 1.86 & $0.57 \mathrm{a}$ & $0.51 \mathrm{a}$ & $0.3 \mathrm{a}$ & 0.28 \\
\hline GHR-94+120mg CdSO & 1.91 & 1.83 & $0.53 \mathrm{a}$ & $0.52 \mathrm{a}$ & 0.27 & 0.26 \\
\hline $\mathrm{GHF} 162+60 \mathrm{mg} \mathrm{CdSO}_{4}$ & 1.95 & 1.94 & $0.56 \mathrm{a}$ & $0.54 \mathrm{a}$ & $0.31 \mathrm{a}$ & $0.30 \mathrm{a}$ \\
\hline GHF-162+120mg CdSO $_{4}$ & 1.98 & 1.92 & $0.59 \mathrm{a}$ & $0.53 \mathrm{a}$ & $0.34 \mathrm{a}$ & $0.32 \mathrm{a}$ \\
\hline GHF-281+60mg CdSO 4 & $2.08 \mathrm{a}$ & 2.01 & $0.66 \mathrm{a}$ & $0.65 \mathrm{a}$ & $0.35 \mathrm{a}$ & $0.33 \mathrm{a}$ \\
\hline $\mathrm{GHF}_{281+120 \mathrm{mg} \mathrm{CdSO}_{4}}$ & $2.25 \mathrm{a}$ & $2.22 \mathrm{a}$ & $0.71 \mathrm{a}$ & $0.65 \mathrm{a}$ & $0.38 \mathrm{a}$ & $0.35 \mathrm{a}$ \\
\hline GHF-3153+60mg CdSO 4 & $2.47 \mathrm{a}$ & $2.38 \mathrm{a}$ & $0.82 \mathrm{a}$ & $0.77 \mathrm{a}$ & $0.39 \mathrm{a}$ & $0.38 \mathrm{a}$ \\
\hline GHF-3153+120mg CdSO 4 & $2.62 \mathrm{a}$ & $2.54 \mathrm{a}$ & $0.67 \mathrm{a}$ & $0.61 \mathrm{a}$ & $0.42 \mathrm{a}$ & $0.42 \mathrm{a}$ \\
\hline$L S D(P=0.05)$ & 0.32 & 0.31 & 0.11 & 0.09 & 0.08 & 0.08 \\
\hline
\end{tabular}

Column values followed by the (a) are significantly different with control according to Fisher's LSD test $(P=0.05)$.

\subsubsection{Effect of $\mathrm{Cd}$ on nodulation}

Generally, the addition of Trichoderma strains to the Cdtreated soil as co-inoculating agent improved the nodulation potent of the four $S$. meliloti strains. The data for the effect of cadmium on the nodulation potential of alfalfa plants with the inoculants are present in Table 3. All plants were nodulated even in the presence of the highest concentration (120mg Cd/kg soil), but with a few number of nodules. In all cases of the $\mathrm{Cd}$, the number of nodules per plant varied directly with the metal concentrations applied to the soil. There were significant differences between the number of nodules throughout the all plants and the highest concentration of $\mathrm{Cd}$ applied to the soil. Moreover, that number of root nodules which was counted at $60 \mathrm{mg} / \mathrm{kg}$ was significantly increased compared with those at $120 \mathrm{mg} / \mathrm{kg}$. 
strain. While the lowest nodule number and nodule dry weight was found at the combination of plant grown in soil amended with $120 \mathrm{mg} \mathrm{Cd}\left(\mathrm{CdSO}_{4}\right) / \mathrm{kg}$ inoculated with Sinorhizobium meliloti strain GHR-94 and coinoculated with Trichoderma viride strains.

Table. 3: Number of nodules and nodules dry weight of Medicago sativa grown in Cd-contaminated soil inoculated with Sinorhizobium meliloti in presence or in absence of Trichoderma strains.

\begin{tabular}{|c|c|c|c|c|}
\hline \multirow[t]{2}{*}{ Treatments } & \multicolumn{2}{|c|}{ Number of nodules/plant } & \multicolumn{2}{|c|}{ Nodules dry weight (mg) } \\
\hline & T.harzianum & T. viride & T.harzianum & T. viride \\
\hline Control & 0 & 0 & 0 & 0 \\
\hline Control+60mg CdCl 2 & 0 & 0 & 0 & 0 \\
\hline Control+120mg CdCl 2 & 0 & 0 & 0 & 0 \\
\hline GHR-94+60mg CdCl 2 & 32 & 29 & 121 & 118 \\
\hline GHR-94+120mg CdCl 2 & 26 & 21 & 99 & 78 \\
\hline GHF-162+60mg CdCl 2 & $41 \mathrm{a}$ & 34 & 143 & $174 a$ \\
\hline GHF-162+120mg CdCl 2 & 34 & 29 & $175 a$ & 122 \\
\hline GHF-281+60mg CdCl 2 & $54 a$ & $42 \mathrm{a}$ & $211 \mathrm{a}$ & $171 \mathrm{a}$ \\
\hline GHF-281+120mg CdCl 2 & $43 \mathrm{a}$ & 33 & $176 a$ & 134 \\
\hline GHF-3153+60mg CdCl 2 & $65 a$ & $51 \mathrm{a}$ & $224 a$ & $199 a$ \\
\hline GHF-3153+120mg CdCl 2 & $51 \mathrm{a}$ & $39 a$ & $196 a$ & $162 \mathrm{a}$ \\
\hline GHR-94+60mg CdSO 4 & 28 & 25 & 116 & 98 \\
\hline GHR-94+120mg CdSO 4 & 23 & 19 & 92 & 81 \\
\hline GHF-162+60mg CdSO 4 & $37 \mathrm{a}$ & 31 & 129 & 122 \\
\hline GHF-162+120mg CdSO 4 & 31 & 26 & 123 & 102 \\
\hline GHF-281+60mg CdSO 4 & $49 a$ & $38 \mathrm{a}$ & $196 a$ & $155 \mathrm{a}$ \\
\hline GHF-281+120mg CdSO 4 & 39 & 30 & 156 & 121 \\
\hline GHF-3153+60mg CdSO 4 & $58 \mathrm{a}$ & $46 a$ & $248 \mathrm{a}$ & $201 \mathrm{a}$ \\
\hline $\mathrm{GHF}^{2} 3153+120 \mathrm{mg} \mathrm{CdSO}_{4}$ & $51 \mathrm{a}$ & $39 a$ & $202 a$ & $162 a$ \\
\hline $\operatorname{LSD}(P=0.05)$ & 15.5 & 14.8 & 74.8 & 62.5 \\
\hline
\end{tabular}

Column values followed by the (a) are significantly different with control according to Fisher's LSD test $(P=0.05)$.

Comparatively, the results showed high significant differences (at $P=0.05$ ) in the plant inoculated by either GHF-3153 or GHF-281 in the presence of Trichoderma harzianum strains and grew in soil polluted with $60 \mathrm{mg}$ $\mathrm{Cd} / \mathrm{kg}$.

\subsubsection{Effect of Cd on total chlorophylls content}

The results of the present study showed that the addition of Trichoderma strains to the $\mathrm{Cd}$ amended soil as coinoculating agent improved the chlorophyll content in the plant leaves especially those incoculated with the four $S$. meliloti strains compared with the control plants. The data for the effect of cadmium on the chlorophyll content of the alfalfa plants with the inoculants are present in Fig 5. All plants were grown even in the presence of the highest concentration (120 mg Cd/ $\mathrm{kg}$ soil), and the leaves were more healthy than those of control pots or even better than those of only inoculated by biofertilizers or coinoculated with Trichoderma strains only. In all cases of the $\mathrm{Cd}$, the chlorophyll content per plant varied directly with the metal concentrations applied to the soil as well as with the microbial inoculation. There were significant differences between the chlorophyll content throughout the all plants and the highest concentration of $\mathrm{Cd}$ applied to the soil. Moreover, that chlorophyll content at 60 $\mathrm{mg} / \mathrm{kg}$ was significantly increased compared with those at $120 \mathrm{mg} / \mathrm{kg}$.

The results of this study showed that the coinoculation with $T$. harzianum increased the chlorophyll content compared with those coinoculated with $T$. viride strain especially when the plant inoculated by GHR-94 followed by GHF-3153, GHF-281 and GHF-162. The lowest chlorophyll content was at control plant grown in untreated soil and control plant grown in soil amended with $120 \mathrm{mg} \mathrm{Cd} / \mathrm{kg}$. 


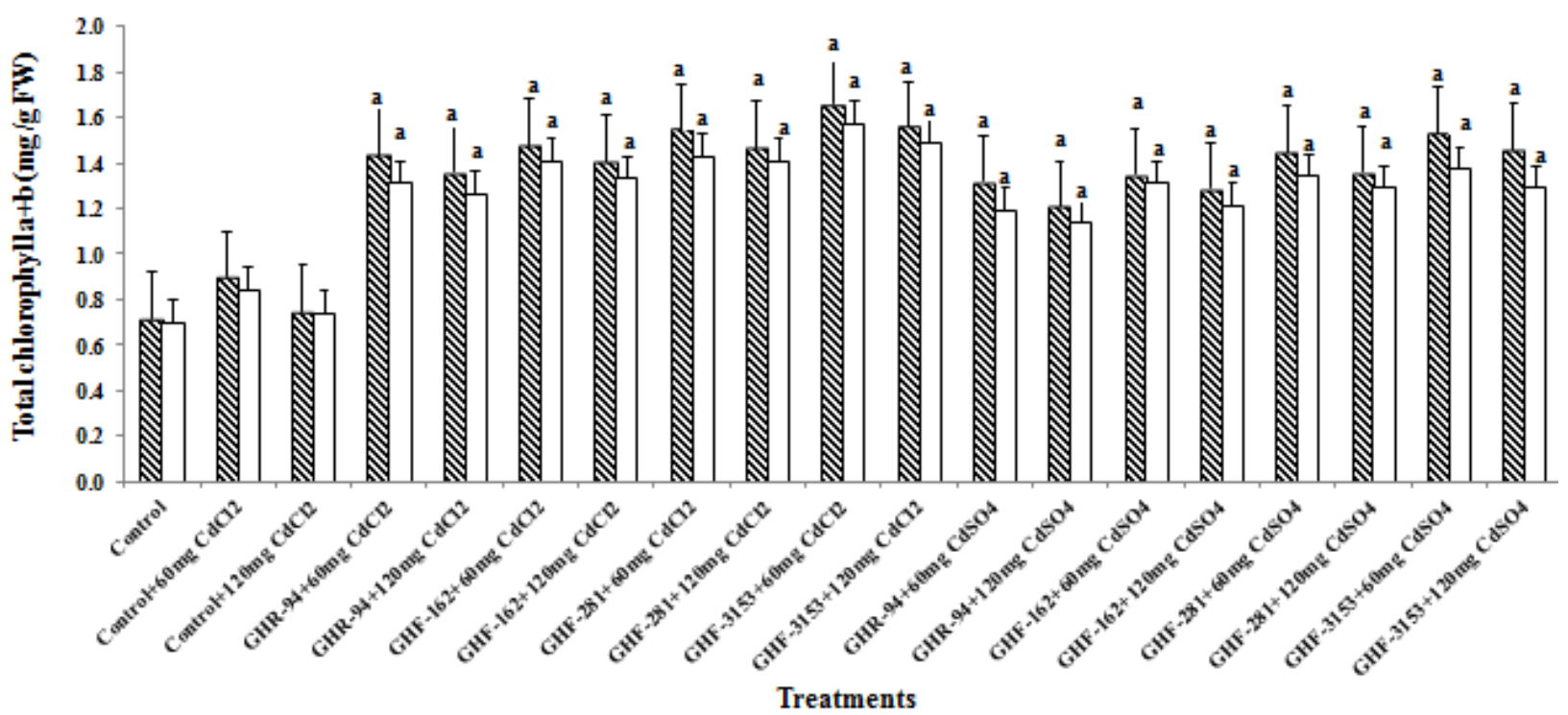

Fig. 5: Total chlorophyll of Medicago sativa grown in Cd-contaminated soil inoculated with Sinorhizobium meliloti in presence or in absence of Trichoderma strains.

\subsubsection{Effect of Cd on shoot N, P and K content}

Generally, it was found that $\mathrm{CdCl}_{2}$ more stimulated the bioaccumulation of $\mathrm{N}, \mathrm{P}$ and $\mathrm{K}$ in plant shoot more than those plants grew in soil polluted with $\mathrm{CdSO}_{4}$. Table 4 shows that the all parameters of the investigations recorded in $\mathrm{CdCl}_{2}$ soil pollution were higher in $\mathrm{N}, \mathrm{P}$ and $\mathrm{K}$ content in plant shoot than those measured in soil polluted with $\mathrm{CdSO}_{4}$. Also, the higher investigated parameters were registered in plants inoculated with GHF-3153 or GHF-281 and coinoculated with T.harzianum strain and grew in $60 \mathrm{mg} \mathrm{Cd} / \mathrm{kg}$ polluted soil. The results of the present study showed that even in $\mathrm{CdSO}_{4}$ or in $\mathrm{CdCl} 2$ polluted soils, plant nutritional status give significant differences under most of the treatments at $\mathrm{P}=0.05$ compared with the control.

Table. 4: Shoot N, P and K content of Medicago sativa grown in Cd contaminated soil and inoculated with sinorhizobium meliloti in presence or in absence of Trichoderma strains.

\begin{tabular}{|c|c|c|c|c|c|c|}
\hline \multirow[t]{2}{*}{ Treatments } & \multicolumn{2}{|c|}{$\mathrm{N}$ content (mg/plant) } & \multicolumn{2}{|c|}{$\mathbf{P}(\mathbf{m g})$} & \multicolumn{2}{|c|}{ K (mg) } \\
\hline & T.harzianum & T. viride & T.harzianum & T. viride & T.harzianum & T. viride \\
\hline Control & 114 & 97 & 31 & 29 & 42 & 38 \\
\hline Control+60mg CdCl ${ }_{2}$ & 125 & 121 & 37 & 33 & 46 & 43 \\
\hline Control+120mg CdCl ${ }_{2}$ & 146 & 137 & $45 \mathrm{a}$ & $43 a$ & $55 \mathrm{a}$ & $52 \mathrm{a}$ \\
\hline GHR-94+60mg CdCl ${ }_{2}$ & $187 \mathrm{a}$ & $174 \mathrm{a}$ & $52 \mathrm{a}$ & $46 a$ & $61 \mathrm{a}$ & $58 \mathrm{a}$ \\
\hline GHR-94+120mg CdCl${ }_{2}$ & $177 \mathrm{a}$ & $165 a$ & $45 \mathrm{a}$ & $44 a$ & $56 a$ & $54 a$ \\
\hline GHF-162+60mg CdCl 2 & $201 \mathrm{a}$ & $189 \mathrm{a}$ & $66 a$ & $61 \mathrm{a}$ & $67 \mathrm{a}$ & $62 \mathrm{a}$ \\
\hline GHF-162+120mg CdCl ${ }_{2}$ & $187 \mathrm{a}$ & $179 \mathrm{a}$ & $52 \mathrm{a}$ & $49 \mathrm{a}$ & $62 \mathrm{a}$ & $59 a$ \\
\hline GHF-281+60mg CdCl 2 & $235 \mathrm{a}$ & $224 a$ & $74 a$ & $69 \mathrm{a}$ & $76 a$ & $71 \mathrm{a}$ \\
\hline GHF-281+120mg CdCl ${ }_{2}$ & $211 \mathrm{a}$ & $208 \mathrm{a}$ & $54 a$ & $51 \mathrm{a}$ & 59 & $55 \mathrm{a}$ \\
\hline GHF-3153+60mg CdCl 2 & $254 \mathrm{a}$ & $247 \mathrm{a}$ & $82 a$ & $76 a$ & $82 \mathrm{a}$ & $74 a$ \\
\hline GHF-3153+120mg CdCl & $239 a$ & $232 a$ & $56 a$ & $52 a$ & $66 a$ & $63 a$ \\
\hline Control+60mg $\mathrm{CdSO}_{4}$ & $115 \mathrm{a}$ & 111 & 32 & 30 & 41 & 39 \\
\hline Control+120mg $\mathrm{CdSO}_{4}$ & 137 & 131 & 41 & 39 & 35 & 31 \\
\hline GHR-94+60mg CdSO 4 & $167 \mathrm{a}$ & $154 \mathrm{a}$ & $52 a$ & 42 & $51 \mathrm{a}$ & $48 \mathrm{a}$ \\
\hline GHR-94+120mg CdSO 4 & 155 & $147 \mathrm{a}$ & 44 & 41 & 50 & $47 \mathrm{a}$ \\
\hline GHF-162+60mg CdSO ${ }_{4}$ & $181 \mathrm{a}$ & $179 \mathrm{a}$ & $56 a$ & $51 \mathrm{a}$ & $57 \mathrm{a}$ & $52 \mathrm{a}$ \\
\hline GHF-162+120mg CdSO 4 & $176 \mathrm{a}$ & $165 \mathrm{a}$ & $53 a$ & $45 \mathrm{a}$ & $52 \mathrm{a}$ & $49 a$ \\
\hline
\end{tabular}




\begin{tabular}{|c|c|c|c|c|c|c|}
\hline \multirow[t]{2}{*}{ Treatments } & \multicolumn{2}{|c|}{$N$ content (mg/plant) } & \multicolumn{2}{|c|}{$\mathbf{P}$ (mg) } & \multicolumn{2}{|c|}{ K (mg) } \\
\hline & T.harzianum & T. viride & T.harzianum & T. viride & T.harzianum & T. viride \\
\hline GHF-281+60mg CdSO 4 & $224 a$ & $218 \mathrm{a}$ & $61 \mathrm{a}$ & $56 a$ & $72 a$ & $70 \mathrm{a}$ \\
\hline GHF-281+120mg CdSO 4 & $219 a$ & $206 a$ & $56 a$ & $53 a$ & $69 \mathrm{a}$ & $65 a$ \\
\hline $\mathrm{GHF} 3153+60 \mathrm{mg} \mathrm{CdSO}_{4}$ & $244 a$ & $232 \mathrm{a}$ & $72 a$ & $66 a$ & $72 a$ & $64 a$ \\
\hline GHF-3153+120mg CdSO 4 & $229 a$ & 221 & $65 a$ & $64 a$ & $68 \mathrm{a}$ & $61 \mathrm{a}$ \\
\hline$L S D(P=0.05)$ & 43.5 & 43.6 & 13.4 & 12.6 & 12.3 & 11.5 \\
\hline
\end{tabular}

Column values followed by the (a) are significantly different with control according to Fisher's LSD test $(\mathrm{P}=0.05)$.

\subsubsection{Rhizobioremediation and Cd accumulation in} shoot:

Fig 6 demonstrates the $\mathrm{Cd}$ uptake by plant shoot throughout the interactions between the rhizomicroorganisms and the absorption surfaces of the plant root. The present study showed that the Cd uptake by plant roots with the association with the biofertilizer Sinorhizobium and Trichoderma as coinoculating agents was higher in soil polluted with $\mathrm{CdSO}_{4}$ than in soil polluted with $\mathrm{CdCl}_{2}$. The more $\mathrm{Cd}$ accumulation in the shoot of the alfalfa plant was more in plant roots coinoculate with Trichoderma harzianum than those coinoculated with Trichoderma viride. Also, the amount of $\mathrm{Cd}$ detected in the shoot of the plant was more in those plants grown in the soil polluted with $120 \mathrm{mg} \mathrm{Cd} / \mathrm{kg}$ than in soil polluted with $60 \mathrm{mg} \mathrm{Cd} / \mathrm{kg}$. The roots inoculated with GHF-3153 and GHF-281 has the ability to absorb $\mathrm{Cd}$ in high polluted soil better than the soil polluted with low dose of $\mathrm{Cd}$. From the Fig 6 below, the results can summarized as following: Highest $\mathrm{Cd}$ accumulation in alfalfa shoot is found the case of: (a) Inoculationg the plant roots with GHF-3153 or by GHF-281 and coinoculating with Trichoderma harzianum and grow in soil polluted with $120 \mathrm{mg} \mathrm{Cd} \quad\left(\mathrm{CdSO}_{4}\right) / \mathrm{kg}$. (b) Inoculationg the plant roots with GHF-3153 or by GHF281 and coinoculating with Trichoderma harzianum and grows in soil polluted with $120 \mathrm{mg} \mathrm{Cd}\left(\mathrm{CdCl}_{2}\right) / \mathrm{kg}$.

Lowest $\mathrm{Cd}$ accumulation in alfalfa shoot is found the case of: (a) Control and (b) Plant grown in soil of low $\mathrm{Cd}$ concentration. The use of term rhizobiremediation her can be replace the term phytoremediation because that the complete system of cooperation is interacted together to tolerate the system against the free $\mathrm{Cd}$ ions and allow some of them to be bioabsorbed and bioaccumulated in the plant parts as well as accumulated in the cells of Sinorhizobium or Trichoderma.
Trichoderma harzianum $\square$ Trichoderma viride

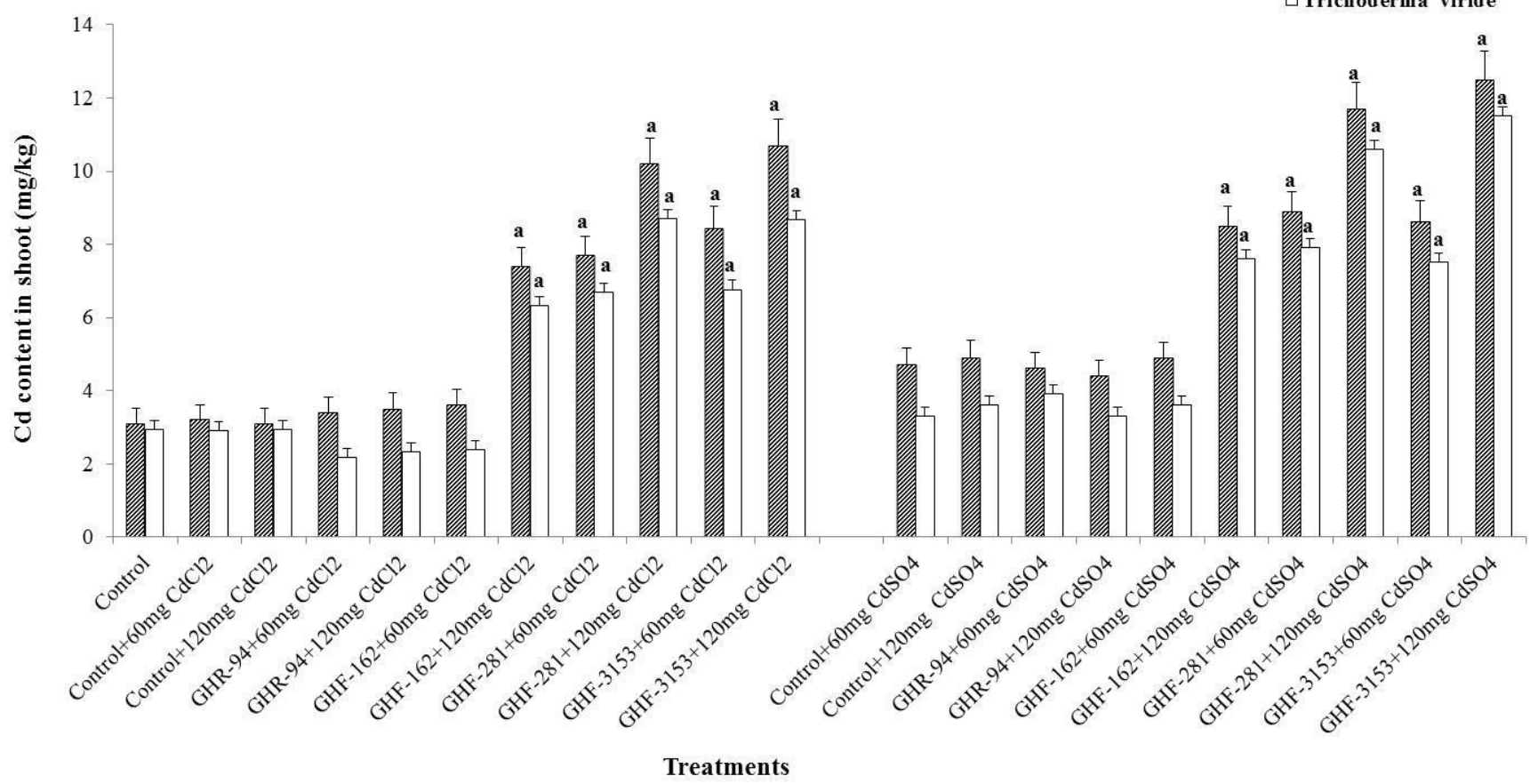

Fig. 6: Shoot Cd content of Medicago sativa grown in Cd amended soil and inoculated with Sinorhizobium meliloti in presence or in absence of Trichoderma strains. Bar values indicate by (a) are significantly different with control according to Fisher's LSD test $(P=0.05)$. 


\section{DISCUSSION}

Morrissey et al., (2004) reported that one major challenge for the twenty-first century will be the production of sufficient food-the United Nations Population Fund estimates that the global human population may well reach 10 billion by 2050 . This means increasing agricultural productivity of food crops, as plants form the basis of every food chain. The introduction of metal pollutants in various forms in the environment can pose a severe threat to the ecological system due to their negative impact on most life forms (Jaiswal and Malik 2000, Gavrilesea 2004). Although, some amounts of heavy metals are required by all life forms, however, there is a threshold limit to this requirement (Cervantes and Corona 1994). At high concentrations, heavy metal ions react to form toxic compounds in cells (Nies 1999, Choudhury and Spain 2003). Another major problem with metals is their persistence as they tend to persist indefinitely in the food chain (Gupta et al. 2000, Aleem et al., 2003). The conventional treatment procedures used for removal of metals are uneconomical (Say et al., 2001). Therefore, there is a need to develop rapid, economical and environmentally benign technology for the removal of metals from industrial effluents. There are certain microorganisms, which can survive in high concentrations of metals and have the potential to accumulate different metals. This is achieved by the virtue of covalent interaction of metal at cell surface or within the cell by different processes (Gadd and White 1993, Bhanoori and Venkateswerlu, 2000). These microbes can be of immense significance in the clean-up of heavy metals from the environment.

Naár and Biró (2006) established that the rate of $\mathrm{Cd}$ pollution significantly correlated with the frequency of four of six Trichoderma spp. presumably, the $\mathrm{Cd}$ tolerance of the isolates from differently contaminated plots is similar. This fact was supported by an earlier study, in which $\mathrm{Cd}$ tolerance of $T$. harzianum, T. virens, T. viride isolates, originating from soils with different $\mathrm{Cd}$ pollution levels were studied. The authors said that no considerable difference was found in the minimum inhibitory concentration for in vitro growth rate on $\mathrm{Cd}$ containing medium. Our in vitro results showed that the Trichoderma strains can tolerate the different concentration of $\mathrm{Cd}$ in broth medium. Harman et al. (2004) stated that Trichoderma spp. Are free -living fungi that are common in soil and root ecosystems. Root colonization by Trichoderma spp. also frequently enhances root growth and development, crop productivity, resistance to abiotic stresses and the uptake and use of nutrients. Kleifeld and Chet (1992) mentioned that the fungus $T$. harzianum which was applied to pathogen-free soil induced an increase in emergence of seedlings, plant height, leaf area and dry weight. The results of the present study confirm the remarks and we are in agreement with the authors regarding to the increase of the plant dry weight. Bayoumi et al., (1995b) studied the effects of different abiotic factors (acidity, salinity, nitrate and temperature) on growth rate of rootnodule bacteria (Rhizobium and Bradyrhizobium) strains were investigated in vitro. Strains isolated from Vicia faba L., Coronilla varia L. and Lupinus albus L. exhibited a large variation in tolerance of the above mentioned factors. These bacteria should be screened under stimulated conditions for enhanced survival before selection to be used for commercial inoculant production. Linear correlation matrix data were useful to find the appropriate concentrations for the selection of the tolerant strains. This conclusion can be applied to the data obtained during the experimental records. The statistical examinations carried out on the collected results confirm also that conclusion of Bayoumi et al., (1995b). Alfredo et al., (2006) hypothesized that the remediation measures would reduce heavy metal solubility, increase soil fertility and enhance soil microbial functionality. Also they hypothesized that the addition of different amendments and the development of a root system might induce shifts in the microbial community structure among the different treatments. We are in agreement with these concepts with the regard to the increases of nutritional status in the alfalfa biofertilized and coinoculated by functional microbial groups. Naár et al., (2002) mentioned that the rate and direction of correlations, however, varied with the type of heavy metals when pot experiment was carried out to test the relation between two beneficial microorganisms in $\mathrm{Cd}, \mathrm{Zn}$ and $\mathrm{Ni}$ polluted soil. The recorded results are in agreement with these conclusions respecting the mode of action of the microbial functions on the plant production and the nutrient content in the plants. The most remarkable result of this study is the survival of Sinorhizobium strains in the heavy metal contaminated soil which appear to be sensitive to high concentrations of applied cadmium salts.

These results were in agreement with the conclusion of Pálagyi et al., (2004) mentioned that the success of a sinorhizobial inoculant in the soil depends to a large extent on its capacity to compete against indigenous strains. GSM03, a S. meliloti strain with enhanced competitiveness for nodule occupancy, was recently established in soil amended with heavy metals containing high doses of $\mathrm{Cd}, \mathrm{Cu}$ and $\mathrm{Pb}$ ion concentrations. The results allowed us to differentiate between alterations in the microbial community apparently caused by inoculation and by the rhizosphere effect induced by the alfalfa plants and by the environment. Only moderate inoculation-dependent effects could be detected, while the 
alfalfa plants appeared to have a much stronger influence on the microbial community. There are increasing evidence of adverse effects on microbial processes related to nutrient cycling in these types of soils. Applications of organic fertilizers with low concentrations of heavy metals with improve soil fertility in reclaimed soils. Furthermore, the legume-root nodule symbiosis can be used as an effective parameter for ecotoxicological evaluation of contaminated soils, Smith, (1997). However, in our experiment these factors were similar for all treatments.

Our results clearly demonstrate that small concentrations of $\mathrm{Cd}$ in soil cannot cause reductions in the number of rhizobia and indirectly in the nodule number too. These results are in agreement with Giller et al., (1993). AlKahal et al., (2001) mentioned that metal uptake by grains seemed to be directly related to the concentration of heavy metals and was greater in the case of an individual metal added separately than in combination. The results of the present study support this conclusion, but our results showed that the accumulation of $\mathrm{Cd}$ in the plant shoot was depended on the microbial inoculation and the amount of $\mathrm{Cd}$ present in the contaminated soil.

\section{CONCLUSION}

The results indicate that Medicago sativa is suitable to grow and rehabilitate Cd-polluted soils when inoculated specifically with Sinorhizobium meliloti tolerant to cadmium salts at various concentrations. Some other soil microorganisms like and Trichoderma fungi can further improve the chances to recover these contaminated sites and bring them back into cultivation. The association of Medicago sativa with Cd-resistant sinorhizobial strains can further help to improve the resistance of alfalfa to $\mathrm{Cd}$. It can be assumed that such legumes will also support the $\mathrm{N}$ nutrition of the Medicago sativa provided that an effective Sinorhizobim-Medicago association can be established under Cd-polluted conditions.

\section{ACKNOWLEDGEMENTS}

I would like to thank the Higher Education Ministry of Libya for their financial support for this work.

\section{REFERENCES}

[1] Adriano D.C. (1986). Trace Elements in the Terrestrial Environment. Springer-Verlag, New York.

[2] Aleem A., Isar J. and Malik A. (2003). Impact of long-term application of industrial waste water on the emergence of resistance traits in Azotobacter chroococcum isolated from rhizosperic soil. Bioresour. Technol,( 86) pp 7-13.
[3] Alfredo P., Pilar B., Engracia M., Francisco C., Petra J and Michael S. (2006). Microbial community structure and function in a soil contaminated by heavy metals: effects of plant growth and different amendments. J. Soil Biology and Biochemistry, (2) pp 327-341.

[4] Altomare C., Norvell W. A., Björkman T and Harman G. E. (1999). Solubilisation of phosphates and micronutrients by the plant-growth promoting and biocontrol fungus Trichoderma harzianum Rifai 1295-22. Appl. Environ. Microbial.,( 65) pp 29262933.

[5] Anderson T. A and Coat J. R. (1994). Bioremediation though Rhizosphere technology. American Chemical Society, Washington, DC.

[6] Askew D and Laing M. D. (1993). An adapted selective medium for the qualitative isolation of Trichoderma species. Plant Pathol.,( 42) pp 686690.

[7] Baker, A.J.M. (1994). Heavy metal accumulation and tolerance in British populations of the metallophytes Thlaspi cearulescens J. and C. Presl. Brasicaceae, New Phytol,( 127), pp 61-68.

[8] Bayoumi H. E. A. F. (1987). Pesticide and antibiotic sensitivity of Rhizobium leguminosarum strains. University of doctor's thesis. Gödöllö University of Agricultural Sciences. Gödöllö, Hungary. P 93.

[9] Bayoumi H. E. A. F., Biró B and Kecskés M. (1995a). Some of environmental factors influencing the survival of Rhizobium leguminosarum bv. Viceae. Acta Biol. Hung. (46) pp7-30.

[10]Bayoumi H. E. A. F., Biró B and Kecskés M. (1995b). Effect of some of environmental factors on Rhizobium and Bradyrhizobium strains. Acta Microbiol. Immunol. Hung., (42) pp 61-69.

[11]Bhanoori M and Venkateswerlu G. (2000). In vivo chitin -cadmium complexation in cell wall of Neurospora crassa. Biochim. Biophys. Acta., (1519) pp 21-28.

[12] Boularbah A., Schwartz C., Bitton G., Aboudrar W., Ouhammou A and Morel J. L. (2006). Heavy metal contamination from mining sites in South Morocco: 2. Assessment of metal accumulation and toxicity in plants. Chemosphere, (63) pp 811-817.

[13]Brooks R. R. (1998). Geobotany and hyperaccumulators. In: Plants those hyperaccumulate heavy metals. R.R. Brook(ed), CAB Internet. Wallingford, UK, PP 55-94.

[14] Burris R. H. (1974). Methodology. In The Biology of Nitrogen Fixation, pp. 9-33. Edited by A. Quispel. Amsterdam, New York: North Holland Publishing Co. 
[15] Cervantes C., Corona G. F (1994). Copper resistance mechanisms in bacteria and fungi. FEMS Microbiol. Rev. (14) pp 121-138.

[16] Choudhury R. and Srivastava S. (2001). Mechanism of zinc resistance in Pseudomonas Putida strain S4. World J. Microbiol. Biotechnol., (17) pp 149-153.

[17] Cunningham S. D., Berti W. R. and Huang J. W.(1995): phytoremediation of contaminated soils. Tibitech., (13) pp 393-397.

[18] Franco, A. A and Vincent J. M.( 1976) . Competition amongst rhizobial strains for the colonization and nodulation of two tropical legumes. Plant Soil, (45) pp 27-48.

[19] Gadd G. M and White C. (1993). Microbial treatment of metal pollution- a working biotechnology. TIBTECH, (11) pp 353-360.

[20] Gavrilesea M. (2004). Removal of heavy metal from the environment by biosorption . Life Sci. (4) pp 219 -232 .

[21]Giller K. E., Nussbaum R., Chaudri A. M and McGrath S. P. (1993). Rhizobium meliloti is less sensitive to heavy-metal contamination in soil than $R$. leguminosarum bv. trifolii or R. loti, soil Biol. Biochem., (25) pp273-278.

[22] Gray K. M., Pearson J. P., Downie J. A., Bobze B. E and Greeberg E. P. (1996). Cell-to-cell signaling in the symbiotic nitrogen-fixing bacterium Rhizobium leguminosarum: autoinduction of a stationary phase and rhizosphere-expressed genes J. Bacteriol., (178) pp 372-376.

[23] Grayston S. J and Campbell C. D. (1996). Functional biodiversity of microbial communities in the rhizospheres of hybrid larch (Larix eurolepis) and sitka spruce (Picea sitchensis). Tree physiol., (16) pp 1031-1038.

[24] Grayston S. J., Vaughan D and Jones D. (1996). Rhizosphere carbon flow in trees, in comparison with annual plants: the importance of root exudation and its impact on microbial activity and nutrient availability. Appl. Soil Ecol., (5) pp 29-56.

[25] Grayston S. J., Wang S., Campbell C. D and Edwards A. C. (1998). Selective influence of plant species on microbial diversity in the rhizosphere. Soil Biol. And Biochem., (30) pp 112-121.

[26] Gupta R., Ahuja P., Khan S., Saxena R. K and Mohapatra H. (2000). Microbial biosorbents: meeting challenges of heavy metal pollution in aqueous solutions. Curr. Sci., (78) pp 976- 983.

[27] Harman G. E., Howell C. R., Viterbo A., Chet I and Lorito M. (2004). Trichoderma species opportunistic, avirulent plant symbionts. Nat. Rev. Microbiol., (2) pp 43-56.
[28] Hiltner L. (1904). Uber neuere Erfahrungen und Probleme auf dem Gebiete der Bodenbakteriologie unter besonderden berucksichtigung und Brache. Arb. Dtsch. Landwirtsch. Gesellschaft (98 ) pp 5978.

[29] Jaiswal R. and Malik A. (2000). Metal resistance in Pseudomonas strain isolated from soil treatment with industrial wastewater. World J. Microbiol. Biotech, (16) pp 177-182.

[30] Jansen R. H and Strijdom B. W. (1982). Competitive abilities of Rhizobiurn meliloti strains considerd to have potential as inoculants. Appl. Environ. Microbiol. (44) pp98-106.

[31] Jordan D. C and Garrard, E. H. (1951). Studies on legume root nodule bacteria. I. Detection of effective and ineffective strains. Can. J. Bot., (29) pp 360-372.

[32] Kabata-Pendias A. (1992).Trace metals in soils in Poland-occurrence and behaviour, Soil Sci., (140) pp 53-70.

[33] Kapulnik Y., Okon Y and Henis Y. (1985). Channges in root morphology of wheat caused by Azospirillum inoculation. Can. J. Microbiol., (31) pp 881-887.

[34] Khan A. G. (2003). Vetiver grass as an ideal phytosymbiont for Glomalian fungi for ecological restoration of derelict land. In: Proceedings of the third international conference on vetiver and exhibition: vetiver and water. China Agricultural Press, Beijing, pp 466-474.

[35] Kirk J. L., Klironomos J. N., Lee H and Trevors J. T. (2005). The effects of perennial ryegrass and alfalfa on microbial abundance and diversity in petroleum contaminated soil. Environ. Poll. (133) pp 455-465.

[36] Kleczowska J., Nutman P. S., Skinner F. A and Vincent J. M. (1968). The identification and classification of Rhizobium. In: B.W.M. Gibbs, D. A. Shapton (eds). Identification methods for microbiologists, part B. Acad. Press, N. Y and Lond., pp 51-65.

[37] Kleifeld O and Chet I. (1992). Trichoderma harzianum interaction with plants and effect on growth-respone. Plant and soil,( 144) pp 267-272.

[38] Kozdroj J and Van Elsas J. D. (2000). Response of the bacterial community to root exudates in soil polluted with heavy metals assessed by molecular and cultural approaches. Soil Biol. Biochem., (32) pp 1405- 1417.

[39] Lichtenthaler H. K. (1987). Chlorophyll Fluorescence signatures of leaves during the autumnal chlorophyll breakdown. J. Plant Physiol., (131) pp 101-110.

[40] Linger P., Mussing J., Fischer $\mathrm{H}$ and Kobert J. (2002). Industrial hemp (Cannabis sativa L.) growing on heavy metal contaminated soil: fibre quality and 
phytoremediation potential. Ind Crops Prod., (16) pp33-42.

[41] Mikanova O., Kubat J., Mikhailovskaya N., Voros I and Biro B. (2001). Influence of heavy metal pollution on some soil-biological parameters in the alluvium of the Litavka River. Rostlinna Vyroba, (47) pp 117-122.

[42] Mingorance M. D. (2002). Focused microwaveassisted digestion of vegetal materials for the determination of essential mineral nutrients. Anal. Bioanal. Chem., (373) pp153-158.

[43] Mordukhava E. A., Skvortsova N. P., Kochetkov V. V., Dubeikovskii A. N and Boronin A. M. (1991). Synthesis of the phytohormone indole-3-acetic acid by rhizosphere bacteria of the genus Pseudomonas. Mikrobiol., (60) pp 494-500.

[44] Morel, J. L., Bitton G., Schwartz. C and Schiavon M. (1997). Bioremdiation of soils and waters contaminated with micropollutants, with role of plants. In Ecotoxicology, Responses, Biomarkers and Risk Assessment. J. J. Zelikoff, J. M. Lynch, J. Shippers, OECD, pp 1-38.

[45] Morrissey J. P., Dow J. M., Mark G. L and O'Gara F. (2004). Are microbes at the root of a solution to world food production? Rational exploitation of interactions between microbes and plants can help to transform agriculture. EMBO reports, (5) pp 922-926.

[46] Naár Z and Biró B. (2006). Species composition of Trichoderma fungi affected by $\mathrm{Cd}, \mathrm{Ni}$ and $\mathrm{Zn}$ in calcareous chernozem soil. Agrochemistry and soil, (55) pp 261- 270.

[47]Naár Z., Román F and Füzy A. (2002). Correlation between indigenous mycoparasitic and symbiotic beneficial fungi at heavy metal stress. Agrochemistry and soil, (51) pp 115-122.

[48] Nies D. H. (1999). Microbial heavy-metal resistance. Appl. Microbial. Biochem., (51) pp 730-750.

[49] Pálagyi A., Bayoumi H. E. A. F., Tóth Nikolett and Kecskés M. (2004). Toxicity effect of $\mathrm{Cd}^{2+}, \mathrm{Cu}^{2+}$ and $\mathrm{Pb}^{2+}$ ion on nodulation potential of Sinorhizobium meliloti on Medicago sativa root in the presence of fluorescent Pseudomonas strain. Proceeding of the VII. International Ph.D. Students Conference. RNDr. University of South Bohemia, Faculty of Agriculture, Czech Republic. pp 55-60.

[50] Peralta-Videa J. R., Gardea- Torresdey J. L., Gomez E., Tiemann K. J., Parsons J. G and Rosa G. (2002). Potential of alfalfa plant to phytoremediate individually contaminated montmorillonite soils with Cd (II), Cr(VI), Cu(II), Ni(II) and $\mathrm{Zn}(\mathrm{II})$. Bull. Environ. Contam. Toxicol., (69) pp 74-81.
[51] Reynders L and Vlassik K. (1982). Use of Azospirillum brasilense as biofertilizer in intensive wheat cropping. Plant and soil, (66) pp 217-223.

[52] Robleto E. A., Kmiecik K., Oplinger E. S., Nienhuis J and Triplett E. W. (1998). Trifolitoxin production increases nodulation competitiveness of Rhizobium etli CE3 under agricultureal conditions. Appl. Environ. Microbiol.,(64)pp 2630-2633.

[53] Sarig S., Blum A and Okon Y. (1988). Improvement of water status and yield of field-grown sorghum (Sorghum bicolor) by inoculation with Azospirillum brasilense. J. Agric. Sci., (110) pp 271- 277.

[54] Say R., Denizil A and Arica Y. (2001). Biosorption of cadmium (II), lead (II) and copper (II) with filamentous fungus Phenarochaete chrysosporium. Bioresourc. Technol., (76) pp 67-70.

[55] Sokal R and Rohlf F. J. (1981). Biometry: The principles and Practice of Statistics in Biological Research, Freeman and Co., New York.

[56] Somasegaran, P. and Hoben, H.J. (1994). Handbook of Rhizobia. Methods in Legume-Rhizobium Technology. Springer-Verlag, New York, NY, pp 450.

[57] Spain A. (2003). Implication of microbial heavy metal tolerance in the environment, Rev. Under. Grad. Res. (2) pp1-6.

[58] Smith S.R (1997). Rhizobium in soils contaminated with copper and zinc following the long-term application of sewage sludge and other organic wastes. Soil Biology and Biochemistry (29) pp14751489.

[59] Stratton M. L., Good G. L and Barker A. V. (2001). The effects of nitrogen source and concentration on the growth and mineral composition of privet. $\mathrm{J}$. Plant Nutr, (24) pp 1745-1772.

[60] Sullivan J. T and Ronson C. W. (1998): Evolution of rhizobia by acquisition of a $500 \mathrm{~kb}$ symbiosis island that integrates into phe-tRNA gene. Proc. Natl. Acad. Sci. USA.,( 95) pp 5145- 5149.

[61] Ta T. C. and Faris M. A. (1988). Environmental effects on the fixation and transfer of nitrogen from alfalfa to associated timothy. Plant and Soil (107) pp 25-30.

[62] Triplett E. W and Sadowsky M. J., (1992). Genetics of competition for nodulation of legumes. Annu. Rev. Microbiol., (46) pp 399-428.

[63] Vander Lelie D. (1998). Biological interactions: the role of soil bacteria in the bioremediation of heavy metal polluted soils. In Metal contaminated soils: in situ inactivation and phytorestoration. J Vangronsveld, S. D. Cunningham (eds), Springer and RG Landes Co., Austin, TX, USA, PP31-50. 
[64] Vincent, J. M. (1970). A Manual for the Practical Study of Root Nodule Bacteria. Oxford: Blackwell Scientific

[65] Wang Z. W., Shan X. Q and Zhang S. Z.(2002). Comparison between fractionation and bioavailability of trace elements in rhizosphere and bulk soils. Chemosphere (46) pp. 1163- 1171. 